\title{
Plantar Pressure Distribution During and after Pregnancy and the Effect of Biomechanical Shoes
}

\author{
Kateřina Kolářová - Martin Zvonař - Martin Vaváček - Igor Duvač - Martin Sebera \\ Faculty of Sports Studies, Kinesiology department, Masaryk University, Brno, Czech Republic
}

Received $10^{\text {th }}$ November 2016; accepted $14^{\text {th }}$ June 2017

\section{DISTRIBUCE PLANTÁRNÍHO TLAKU V PRŮBĚHU TĚHOTENSTVÍ A PO NĚM A VLIV BIOMECHANICKÉ OBUVI}

\begin{abstract}
ABSTRAKT Úvod: Náš výzkum byl zaměřen na objektivní data týkající se změn plantárního tlaku v průběhu těhotenství a po porodu, jakož i na možnost ovlivnit tyto změny pomocí speciální biomechanické obuvi, vyvinuté ve spolupráci Masarykovy univerzity s firmou J Hanák R, s.r.o.; Výzkumné metody: Výzkumu se zúčastnilo 38 těhotných žen, kterým byl na plantografické desce Emed ${ }^{\circledR}$-at měřen plantární tlak v prvním a třetím trimestru těhotenství a po porodu. Dvacet jedna z těchto žen (experimentální skupina) nosilo v daném období speciální biomechanickou obuv. Při měření byly zjištovány hodnoty plantárního tlaku a jeho časového integrálu v 10 oblastech pravé a levé nohy. Data byla poté zpracována pomocí ANOVA a Tukeyho post-hoc testů; Výsledky: Hlavními zjištěními byly statisticky významné nárůsty plantárního tlaku pod podélnou nožní klenbou a mediálním přednožím v průběhu těhotenství v obou výzkumných skupinách a následný pokles většiny hodnot po porodu. Statisticky významné rozdíly mezi hodnotami v experimentální a kontrolní skupině nebyly zjištěny; Závěr: Zatížení nohy se v průběhu těhotenství přesouvá dopředu a mediálně, což představuje větší zátěž především pro podélnou nožní klenbu, mediální metatarzální hlavy a palec. Po porodu se vzorec distribuce plantárního tlaku převážně vrací do stavu pozorovaného na začátku těhotenství. Vliv biomechanické obuvi na nohu se v tomto výzkumu nepodařilo prokázat.
\end{abstract}

KLÍČOVÁ SLOVA plantární tlak; těhotenství; chůze; biomechanická obuv

ABSTRACT Background: The study is focused on objective data about plantar pressure changes during pregnancy and after birth, as well as the possibility to affect changes in plantar pressure by wearing special biomechanical shoes developed in cooperation between Masaryk university and J Hanák R, Ltd; Methods: Plantar pressure data of 38 pregnant women were measured in the first and third trimesters, and after birth with Emed ${ }^{\circledR}$-at plantographic platform. Twenty-one of the subjects (experimental group) wore special biomechanical shoes during this period. Peak plantar pressure and pressure time integral values in 10 masks of the right and left foot were measured separately and processed through ANOVA and Tukey post-hoc tests; Results: The main findings were significant increases in plantar pressure values under the longitudinal arch and medial forefoot region during the pregnancy in both groups, and a decrease in most of the values after birth. There were no statistically significant differences in measured values between the groups; Conclusions: The load of the foot shifts during the pregnancy in a forward medial direction, which puts more loads on the longitudinal arch, medial metatarsal head areas and the big toe. After birth, the plantar pressure distribution patterns mostly return to the original state observed at the beginning of pregnancy. The effect of the biomechanical shoes on the foot was not proved.

KEY WORDS plantar pressure; pregnancy; gait; biomechanical shoes

\section{BACKGROUND}

Pregnancy is related with many musculoskeletal changes that might reduce the ability of pregnant women to move without pain. Growing mass on the abdominal side of the body causes different loading of the spine and center of gravity shifting (Roztočil, 2008). Together with changes and pain in the pelvis (Robinson et al., 2010), weight gain and relaxed ligaments (Zwinger et al., 2004), it also contributes to changes in the foot (Segal, 2013) and might cause changes in gait patterns which 

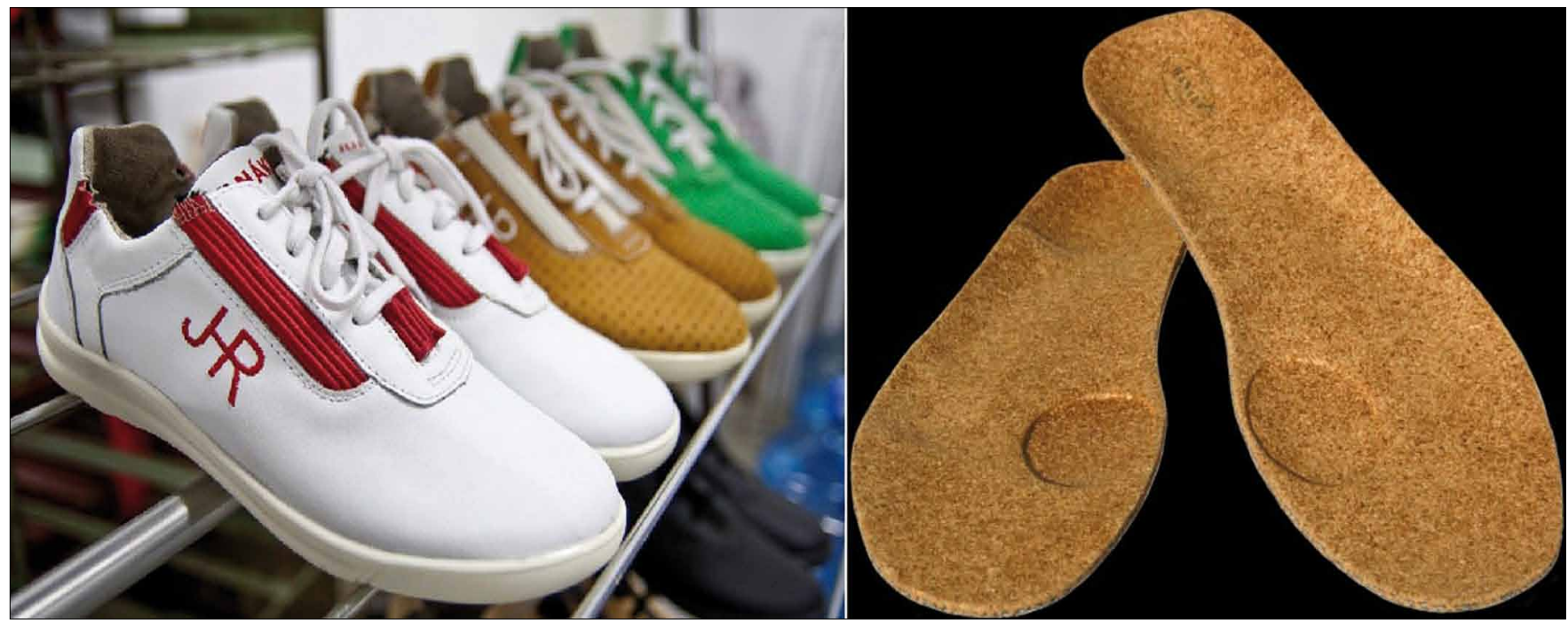

Figure 1. Upper and insole of tested shoes.

is a point of interest in our study. Our aim is to detect the changes in plantar pressures during barefoot walking and to affect the changes in these variables by wearing special biomechanical shoes made by J Hanák R, Ltd, instead of common shoes.

We firstly aim to add further information about dynamic loading of women's feet during pregnancy and after birth to the results of other studies (Nyska et al., 1997; Gaymer et al., 2009; Kardag - Saygi et al., 2010; Ribeiro et al., 2011). Data we get from our control group should be more detailed because of dividing the foot in more regions of left and right foot separately compared to other studies. Our next goal is to verify the effect of wearing specific biomechanical shoes (instead of common shoes) on plantar pressure changes through the comparison of the control and the experimental group. All the pregnant women in the experimental group wore biomechanical shoes. Tested shoes consist of patented insoles J Hanák R, Ltd. which are made of pressed cork and its most prominent feature is a depression under the first metatarsophalangeal joint to promote a more balanced loading of all the toes when walking. This stimulates the muscles and connective tissue structures of transverse arch. Elastic straps made of leather which are sewn into the shoe upper sole at the instep and the heel sections provide space for the work of the longitudinal arch of the foot and in the heel region together with a depression under the heel portion enables correction of the calcaneus position (Figure 1). The shoes should improve the strength of the foot, encourage its biomechanical skills and thereby minimize the negative impact of mentioned changes on the plantar pressure distribution pattern.

The article refers to the study of plantar pressure changes during pregnancy and after birth in an experimental group of women who wore specific biomechanical shoes compared to the changes in women who wore common shoes.

\section{METHODS}

\section{Ethical approval}

All procedures performed in studies involving human participants were in accordance with the ethical standards of the institutional and national research committee and with the 1964 Helsinki declaration and its later amendments or comparable ethical standards. The ethical committee of the Faculty of Sports gave its approval with the research procedures too. All the subjects gave their consent to participate in the research.

\section{Subjects}

Thirty-eight healthy pregnant women with no known pathologies or neuropathies that could influence plantar pressure took part in our whole research. They were divided to experimental and control group. In the experimental group, there were 21 women (average age $32.3 \pm 3.1$ years, average initial weight $66.7 \pm 10.8 \mathrm{~kg}$, average weight gain during pregnancy $13.2 \pm 3.6 \mathrm{~kg}$, average postpartum measurement weight $67.2 \pm 11.3 \mathrm{~kg}$; meant as mean value \pm standard deviation). The control group included 17 women (average age $28.5 \pm 2.6$ years, average initial weight $62.6 \pm 8.2 \mathrm{~kg}$, average weight gain during pregnancy $13.6 \pm 4.3 \mathrm{~kg}$, average postpartum measurement weight $61.9 \pm 9.6 \mathrm{~kg}$ ). Measurement of the subjects took place between 2010 - 2015 at Masaryk University, Brno, Czech Republic.

The first measurement was performed on all 38 women between 8 th and 13th week of pregnancy when body changes and the weight gain were minimal. Subjects from the experimental group got three pairs of biomechanical shoes within 14 days of the first measurement. The experimental group was required to wear the shoes at least 3 hours a day. The second measurement took place between the 37th and 39th week 


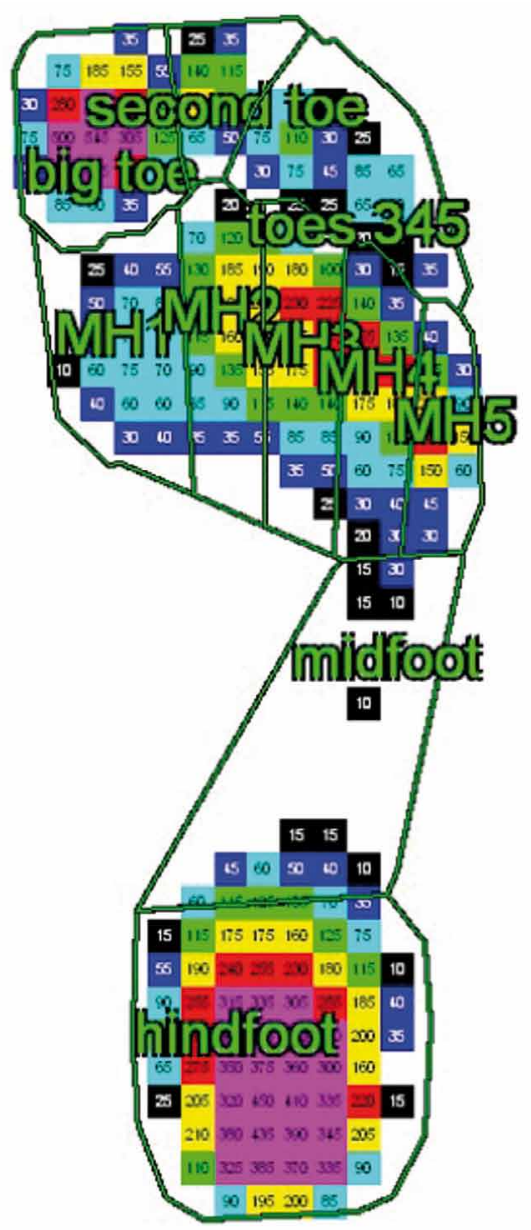

Figure 2. Plantar pressure picture divided in ten regions of interest.

of pregnancy. Some of the women had to be excluded from the research because of premature delivery. The postpartum measurements were made in the period of at least 6 to 12 months after delivery, depending on how fast the mother lost the weight she put on during pregnancy. As getting to initial weight might be problematic in some cases, weight criteria was $0-5 \mathrm{~kg}$ over the initial weight, the average weight losing period took $34.8 \pm 9.5$ weeks in experimental group and 32.6 \pm 9.2 weeks in control group.

\section{Data collection}

Plantar pressure distribution during barefoot walking was measured using the 3-step dynamic protocol (Bus, de Lange, 2005) on plantographic platform Emed $^{\circledR}$-at (Novel, Germany). The subject hits the platform with the third step and walks on so the gait is neither in acceleration nor deceleration phase (Cavanagh, Ulbrecht, 1994). Data for the both the left and right feet were collected during five attempts for each foot (Rosenbaum, Becker 2006). Values from these attempts were averaged and processed with appropriate software (programs Average and Multimask evaluation, Novel, Germany). We focused on peak plantar pressure and pressure time integral in
10 masks - regions of interest (heel, longitudinal arch, I. - V. metatarsal heads, big toe, second toe and other toes).

\section{Data analysis}

For more exact intra individual comparison of changes we converted the measured pressure values of second and third measurement to percentages of the first measurement values. The normal distribution of the values was tested with Lilliefors and Kolmogorov-Smirnov tests of normality. Then the ANOVA and Tukey's post-hoc tests were applied to determine the regions of significant changes and period when the significant changes occurred. We considered the changes to be significant for values of $\mathrm{p}<.05$. We also used coefficient eta-squared to measure effect size in ANOVA. ANOVA was also used to determine differences between the experimental and control group.

\section{RESULTS}

In this section only the statistically significant changes will be mentioned. As an illustration, one complete group of results in two tables with descriptive statistics for pressure time integral for the right foot from experimental and control group can be found in this section (Table 1, Table 2).

\section{Peak pressure}

Changes of peak pressure (PP) represent changes in dynamics of the gait pattern.

For the right foot we found significant changes in PP under the longitudinal arch and fourth metatarsal head region in experimental group and under the second metatarsal head and the big toe region in the control group. PP under the longitudinal arch increased by $28 \%(\mathrm{p}=.00)$ during the pregnancy and decreased by $31 \%(\mathrm{p}=.00)$ after birth in experimental group. There was no significant change of this parameter in the control group. In the fourth metatarsal region in the experimental group we noticed significant postpartum decrease of PP of $15 \%(\mathrm{p}=.03)$. Again, there was no significant change of this parameter in the control group. In the second metatarsal head region in the control group of subjects we found the after birth PP value $10 \%$ higher $(\mathrm{p}=.01)$ than the value from the first trimester. There was no significant difference in experimental group for this region. The last significant change of PP under the right foot was found in the control group where the $\mathrm{PP}$ under the big toe increased during pregnancy by $30 \%(\mathrm{p}=.02)$. No significant change of this parameter was found in the experimental group.

Under the left foot we found significant changes in PP under the longitudinal arch region in both groups and under the big toe in the control group. Under the longitudinal arch we observed an increase of PP during the pregnancy of $28 \%$ ( $\mathrm{p}=$ $.01)$ in the experimental group and of $27 \%(\mathrm{p}=.02)$ in the control group. After birth there was a decrease in PP of $32 \%$ (p $=.00)$ in experimental group whereas there was no significant 


\begin{tabular}{|l|l|l|l|l|l|l|l|l|l|l|l|l|l|l|l|l|l|l|l|l|l|l|l|}
\hline & $\begin{array}{l}\text { total } \\
\text { Mean }\end{array}$ & $\begin{array}{l}\text { total } \\
\text { St.D. }\end{array}$ & $\begin{array}{l}\text { M01 } \\
\text { Mean }\end{array}$ & $\begin{array}{l}\text { M01 } \\
\text { St.D. }\end{array}$ & $\begin{array}{l}\text { M02 } \\
\text { Mean }\end{array}$ & $\begin{array}{l}\text { M02 } \\
\text { St.D. }\end{array}$ & $\begin{array}{l}\text { M03 } \\
\text { Mean }\end{array}$ & $\begin{array}{l}\text { M03 } \\
\text { St.D. }\end{array}$ & $\begin{array}{l}\text { M04 } \\
\text { Mean }\end{array}$ & $\begin{array}{l}\text { M04 } \\
\text { St.D. }\end{array}$ & $\begin{array}{l}\text { M05 } \\
\text { Mean }\end{array}$ & $\begin{array}{l}\text { M05 } \\
\text { St.D. }\end{array}$ & $\begin{array}{l}\text { M06 } \\
\text { Mean }\end{array}$ & $\begin{array}{l}\text { M06 } \\
\text { St.D. }\end{array}$ & $\begin{array}{l}\text { M07 } \\
\text { Mean }\end{array}$ & $\begin{array}{l}\text { M07 } \\
\text { St.D. }\end{array}$ & $\begin{array}{l}\text { M08 } \\
\text { Mean }\end{array}$ & $\begin{array}{l}\text { M08 } \\
\text { St.D. }\end{array}$ & $\begin{array}{l}\text { M09 } \\
\text { Mean }\end{array}$ & $\begin{array}{l}\text { M09 } \\
\text { St.D. }\end{array}$ & $\begin{array}{l}\text { M10 } \\
\text { Mean }\end{array}$ & $\begin{array}{l}\text { M10 } \\
\text { St.D. }\end{array}$ \\
\hline 1 & 100.0 & 0.0 & 100.0 & 0.0 & 100.0 & 0.0 & 100.0 & 0.0 & 100.0 & 0.00 & 100.0 & 0.0 & 100.0 & 0.0 & 100.0 & 0.0 & 100.0 & 0.0 & 100.0 & 0.0 & 100.0 & 0.0 \\
\hline 2 & 108.5 & 12.9 & 112.1 & 20.1 & 126.4 & 28.8 & 124.3 & 28.1 & 112.8 & 18.94 & 112.5 & 19.9 & 116.6 & 26.4 & 100.7 & 32.5 & 108.8 & 25.2 & 134.6 & 41.9 & 113.5 & 38.2 \\
\hline 3 & 101.3 & 13.1 & 103.3 & 16.2 & 99.6 & 26.2 & 104.8 & 18.4 & 102.3 & 13.37 & 100.2 & 14.8 & 98.0 & 18.1 & 100.0 & 39.1 & 95.7 & 30.4 & 121.1 & 52.2 & 109.4 & 51.3 \\
\hline
\end{tabular}

Table 1. Descriptive statistics for PTI for the right foot - experimental group; $\mathrm{N}=63$; all the values are in $\%$

\begin{tabular}{|l|l|l|l|l|l|l|l|l|l|l|l|l|l|l|l|l|l|l|l|l|l|l|}
\hline & $\begin{array}{l}\text { total } \\
\text { Mean }\end{array}$ & $\begin{array}{l}\text { total } \\
\text { St.D. }\end{array}$ & $\begin{array}{l}\text { M01 } \\
\text { Mean }\end{array}$ & $\begin{array}{l}\text { M01 } \\
\text { St.D. }\end{array}$ & $\begin{array}{l}\text { M02 } \\
\text { Mean }\end{array}$ & $\begin{array}{l}\text { M02 } \\
\text { St.D. }\end{array}$ & $\begin{array}{l}\text { M03 } \\
\text { Mean }\end{array}$ & $\begin{array}{l}\text { M03 } \\
\text { St.D. }\end{array}$ & $\begin{array}{l}\text { M04 } \\
\text { Mean }\end{array}$ & $\begin{array}{l}\text { M04 } \\
\text { St.D. }\end{array}$ & $\begin{array}{l}\text { M05 } \\
\text { Mean }\end{array}$ & $\begin{array}{l}\text { M05 } \\
\text { St.D. }\end{array}$ & $\begin{array}{l}\text { M06 } \\
\text { Mean }\end{array}$ & $\begin{array}{l}\text { M06 } \\
\text { St.D. }\end{array}$ & $\begin{array}{l}\text { M07 } \\
\text { Mean }\end{array}$ & $\begin{array}{l}\text { M07 } \\
\text { St.D. }\end{array}$ & $\begin{array}{l}\text { M08 } \\
\text { Mean }\end{array}$ & $\begin{array}{l}\text { M08 } \\
\text { St.D. }\end{array}$ & $\begin{array}{l}\text { M09 } \\
\text { Mean }\end{array}$ & $\begin{array}{l}\text { M09 } \\
\text { St.D. }\end{array}$ & $\begin{array}{l}\text { M10 } \\
\text { Mean }\end{array}$ & $\begin{array}{l}\text { M10 } \\
\text { St.D. }\end{array}$ \\
\hline 1 & 100.0 & 0.0 & 100.0 & 0.0 & 100.0 & 0.0 & 100.0 & 0.0 & 100.0 & 0.00 & 100.0 & 0.0 & 100.0 & 0.0 & 100.0 & 0.0 & 100.0 & 0.0 & 100.0 & 0.0 & 100.0 & 0.0 \\
\hline 2 & 105.5 & 23.6 & 100.6 & 31.3 & 112.7 & 38.7 & 121.2 & 31.3 & 108.7 & 24.3 & 111.5 & 23.4 & 104.4 & 22.2 & 99.1 & 26.9 & 132.9 & 44.8 & 115.1 & 49.5 & 108.2 & 58.0 \\
\hline 3 & 101.1 & 23.0 & 92.8 & 27.0 & 88.1 & 22.4 & 106.1 & 27.1 & 105.3 & 21.7 & 100.3 & 22.0 & 89.8 & 20.2 & 83.9 & 26.7 & 112.0 & 35.3 & 103.5 & 36.1 & 101.9 & 56.4 \\
\hline
\end{tabular}

Table 2. Descriptive statistics for PTI for the right foot - control group; $\mathrm{N}=51$; all the values are in $\%$

change in the control group. Similar to the right foot we found a significant increase $(20 \%, \mathrm{p}=.05)$ in the $\mathrm{PP}$ value under the big toe region during the pregnancy in the control group. No significant changes in this parameter were found in the experimental group.

\section{Pressure time integral}

Pressure time integral (PTI) refers to the total load of the area including pressure and contact time.

More significant changes in PTI were found than in PP. In the right foot the significant changes were found under the heel region in the experimental group, under the longitudinal arch and first metatarsal head regions in both groups, under the second, third and fourth metatarsal heads in the experimental group and under the big toe in the control group. PTI under the right heel increased during the pregnancy by $12 \%(\mathrm{p}=.05)$ in the experimental group. Under the longitudinal arch, PTI increased significantly during the pregnancy by $26 \%(\mathrm{p}=.00)$ in the experimental group. In the control group the increase on the right foot was not significant, but the postpartum decrease was significant in both groups. In the experimental group, PTI decreased by $27 \%(\mathrm{p}=.00)$ so the final value was almost the same as the value from the first trimester, while in the control group the decrease of $25 \%(\mathrm{p}=.02)$ caused the final value to be $12 \%$ lower than the initial value from the first trimester. The load of the first metatarsal head area increased significantly during pregnancy in both groups. Increase of $24 \%(\mathrm{p}=.02)$ was found in the experimental group and increase of $21 \%(\mathrm{p}=$ .03) was found in the control group. Under the second, third and fourth metatarsal heads there were found increases during the pregnancy in the experimental group: $13 \%$ for the second $(\mathrm{p}=.04)$ and third $(\mathrm{p}=.04)$ metatarsal heads and $17 \%(\mathrm{p}=$ $.03)$ for the fourth metatarsal head. Postpartum decrease was significant for the third $(\mathrm{p}=.05)$ and fourth $(\mathrm{p}=.01)$ metatarsal heads regions, where the values fell back to the initial value or slightly under it. There were no significant differences noticed in those regions in control group, except for the decrease under the fourth metatarsal head after birth of $15 \%(\mathrm{p}=.05)$. The last significant change in PTI for the right foot was found under the big toe region in the control group. This value rose during pregnancy by $33 \%(\mathrm{p}=.02)$.

For the left foot the significant changes in PTI were found under the longitudinal arch and the first metatarsal head regions for both groups. Then under the second and third metatarsal heads in the experimental group and the fourth metatarsal head and big toe regions in the control group. Under the longitudinal arch the increase during pregnancy was $24 \%$ ( $\mathrm{p}=$ $.01)$ in the experimental group and $20 \%(\mathrm{p}=.04)$ in the control group. Postpartum decrease of PTI in this area was $24 \%$ ( $\mathrm{p}=$ $.00)$ in the experimental group and $22 \%(\mathrm{p}=.02)$ in the control group. The increase in PTI under the first metatarsal head during pregnancy was $26 \%(\mathrm{p}=.03)$ for experimental group and $19 \%(\mathrm{p}=.01)$ for the control group. After birth, the values of PTI decreased by $24 \%(\mathrm{p}=.05)$ in the experimental group and by $15 \%(\mathrm{p}=.04)$ in the control group. Significant changes in PTI for the second $(\mathrm{p}=.01)$ and third $(\mathrm{p}=.02)$ metatarsal head regions in the experimental group were decreases by $16 \%$ in both regions after birth. There were no significant changes in the control group in these regions. Under the fourth metatarsal head we noticed a significant decrease of $15 \%(\mathrm{p}=.02)$ in the control group during the after birth period. Similar to the right foot, an increase of $26 \%(\mathrm{p}=.03)$ was measured in the big toe region in the control group.

A final comparison of the changes between the experimental and control group through ANOVA showed no significant differences.

\section{DISCUSSION}

In the heel region we found no significant changes in PP which is not in accordance with Ribeiro et al. (2011) who noticed decrease of plantar pressure under the heel during pregnancy. But we can assume that the significant increase of PP we found under the longitudinal arch region shows that most of the heel 
strike impact is immediately shifted toward the shock absorbing mechanism - the longitudinal arch - which hits the floor harder during the pregnancy. This finding is in accordance with findings of Snyder (2001), Ribeiro et al. (2011), Gaymer et al. (2009) and Nyska et al. (1997) who observed a bigger load on the longitudinal arch in pregnant women. In contrast with Gaymer et al. (2009) the decrease in PP after birth under the longitudinal arch was not statistically proved in control group, the final values stayed higher than the initial values. The only significant change under the metatarsal heads for control group was higher value of PP after birth than in first trimester under the second metatarsal head region. In the big toe region we found a significant increase during the pregnancy in the control group. Last two changes point to the forward - medial load shifting during pregnancy, which partly remained after birth.

The most important changes in PTI were noticed under the longitudinal arch and the first metatarsal head, which means that overall load of these two regions tends to be most affected by the somatic changes during and after the pregnancy. Significant increases in both groups for both feet are in accordance with findings of Kardag-Saygi et al. (2010), Ribeiro et al. (2011), Gaymer et al. (2009), Nyska et al. (1997) and Snyder (2001) who found either higher load of the longitudinal arch or higher load of forefoot or both in pregnant women. However, the first metatarsal head belongs to the medial forefoot, where, according to Nyska et al. (1997), the load should be lower during pregnancy which contradicts our findings. Under the fourth metatarsal region we noticed a significant drop in PTI values after birth which proves a positive reaction to the change in conditions. The last significant change in PTI was similar to the $\mathrm{PP}$ results, where an increase in the big toe area in the control group was observed.

In the experimental group we noticed some significant changes that were different from the changes in the control group and might point to the effect of biomechanical shoes. For the PP it was significant decrease under the longitudinal arch after birth. Next difference was the decrease in PP under the right fourth metatarsal head after birth.

As for the PTI values we observed an increase in the right heel region during the pregnancy in experimental group. We also noticed stronger reactions of forefoot to the pregnancy changes in this group. Significantly higher PTI values were found under the second, third and fourth metatarsal heads during the pregnancy and also significant drops in all of these regions after birth.

Although we found some differences in values between the experimental and control group, the significance of the differences was not statistically proved. Maybe a higher number of subjects may help to improve the statistical power of the study.

\section{CONCLUSIONS}

During the study of plantar pressure distribution in 38 pregnant women, divided into experimental (21 subjects who wore special biomechanical shoes) and control (17 subjects who wore common shoes) groups, we found similar significant changes of peak pressure and pressure time integral values during pregnancy and postpartum period in both groups. During the pregnancy, the most significant changes of pressure values were found under the longitudinal arch and first metatarsal head areas in both groups. Mentioned parameters rose during the pregnancy. In the control group we also found a significant increase in values under the big toe. The changes in the plantar pressure values refer to the change of gait and loading pattern when absorbing a harder foot impact in the foot arch and shifting the load in a forward - medial direction in pregnancy. Postpartum, the pressure values in these regions mostly decreased in both groups. There were no statistically significant differences in the changes between the groups, so the effect of the biomechanical shoes was not verified.

\section{LIST OF ABBREVIATIONS}

$\mathrm{PP}$ - peak pressure

PTI - pressure time integral

M01 - mask 1 - heel region

M02 - mask 2 - longitudinal arch region

M03 - mask 3 - first metatarsal head region

M04 - mask 4 - second metatarsal head region

M05 - mask 5 - third metatarsal head region

M06 - mask 6 - fourth metatarsal head region

M07 - mask 7 - fifth metatarsal head region

M08 - mask 8 - big toe region

M09 - mask 9 - second toe region

M10 - mask 10 - other toes region

\section{ACKNOWLEDGEMENTS}

This research was supported by Czech national grant program of Ministry of education registered by Nr. EE2.3.30.0037.

\section{REFERENCES}

Bus, S. A. - de Lange, A. (2005): A comparison of the 1-step, 2-step and 3-step protocols for obtaining barefoot plantar pressure data in the diabetic neuropathic foot. Clinical biomechanics, 20(9), 892-899.

Cavanagh, P. R. - Ulbrecht, J. S. (1994): Clinical plantar pressure measurement in diabetes: rationale and methodology. The Foot, 4(3), 123-135. doi:10.1016/0958-2592(94)90017-5

Gaymer, C. - Whalley, H. - Achten, J. - Vatish, M. - Costa, M. L. (2009): Midfoot plantar pressure significantly increases during late gestation. The Foot, 19(2), 114-116. doi: 10.1016/j.foot.2009.02.001.

Karadag-Saygi, E. - Unlu-Ozkan, F. - Basgul, A. (2010): Plantar Pressure and Foot Pain in the Last Trimester of Pregnancy. Foot \& Ankle International, 31(2), 153-157. doi: 10.3113/FAI.2010.0153.

Nyska, M. - Sofer, D. - Porat, A. - Howard, C. B. - Levi, A. - Meizner, I. (1997): Planter foot pressures in pregnant women. Israel Journal of Medical Sciences, 33(2), 139-146.

Ribeiro, A. P. - Trombini-Souza, F. - de Camargo Neves Sacco, I. - Ruano, R. - Zugaib, M. - João, S. M. (2011): Changes in the Plantar Pressure Distribution During Gait Throughout Gestation. Journal of the American Podiatric Medical Association, 101(5), 415-423. doi: 10.7547/1010415 
Robinson, H. S. - Veierød, M. B. - Mengshoel, A. M. - Vøllestad, N. K. (2010): Pelvic girdle pain - associations between risk factors in early pregnancy and disability or pain intensity in late pregnancy: a prospective cohort study. BMC Musculoskeletal Disorders. doi: 10.1186/1471-2474-11-91

Rosenbaum, D. - Becker, H. P. (2003): Plantar pressure distribution measurements. Technical background and clinical applications. Foot and ankle surgery, 3(1), 1-14. doi:10.1046/j.1460-9584.1997.00043.x

Roztočil, A. et al. (2008): Moderní porodnictví. Praha: Grada Publishing a. s.
Segal, N. A. - Boyer, E. R. - Teran-Yengle, P. - Glass, N. A. - Hillstrom, H. J, - Yack, H. J. (2013): Pregnancy Leads to Lasting Changes in Foot Structure. American Journal of Physical Medicine \& Rehabilitation, 92(3), 232-240. doi: 10.1097/PHM.0b013e31827443a9

Snyder, D. B. (2001): Pregnancy/maternity insoles. http://www.google.com/ patents/US6286232 Accessed 16 October 2015

Zwinger A, et al. (2004): Porodnictví. Praha: Galén. 